\title{
Financial Report Design for Mosque Based on Web
}

\author{
Ahmad ROZIQ ${ }^{*}$, Nur HISAMUDDIN², Moch. SHULTHONI ${ }^{3}$ \\ 1,2,3 University of Jember, Indonesia, Jl. Kalimantan no. 37 Kampus Tegal Boto Jember, East Jawa, Indonesia \\ Email: ahmdroziq.feb@unej.ac.id ${ }^{1}$, hi5am@yahoo.com², shulthoni@unej.ac.id ${ }^{3}$ \\ ${ }^{*}$ Corresponding Author
}

Received: 22.07.2021 $\quad$ Accepted: 02.09.2021 $\quad$ Published: 08.10.2021 $\quad$ DOI: 10.47750/QAS/22.184.24

\begin{abstract}
A non-profit organization is a type of organization that receives funding from resource donors voluntarily, without expecting a reward in the form of a return of benefits in the form of cash or other items of value. In Indonesia, the practice of non-profit-oriented entities operates a lot, one of which is the mosque which is included in a religious organization oriented to social activities with the nuances of shari'ah, where the main activity is as a center of worship for Muslims. Mosques as non-profit entities must meet financial reporting standards that have been approved and issued by the Indonesian Accountants Association (IAI) to maintain the transparency of the entity. ISAK 35, as a guideline for the presentation of financial statements for non-profit-oriented entities, clearly explains how an entity that does not have a profit continues to prepare financial reports for religious entities such as mosques. Web Application is a database application that provides a calculation feature with a multi-functional as the perfect bridge for compiling more relevant and accountable mosque financial reports. Following ISAK 35 guidelines, the output produced by using the Web application to compile mosque financial reports is a list of accounts, general journals, ledgers, trial balances, comprehensive income reports, reports of changes in net assets, and cash flow reports.
\end{abstract}

Keywords: Mosque, Financial Statements, Web Application, ISAK 35

\section{Introduction}

The development of information systems is increasingly widespread with the development of increasingly rapid technology. The need for information systems has begun to enter the various domains of management and management. Information systems that are part of technology become an important part of the field of management. The use of technology aims to make the performance of an organization or group more effective and efficient. Arifin and Pratolo (2012) [5] stated that three aspects must be achieved to achieve the target of the application of information technology, namely: (a) Information technology must have an impact on the creation of service products that are much better than before, both directly and indirectly so that they can improve company performance and competitiveness. (b) Information technology must be able to improve the quality of decision-making for management in the form of providing relevant, precise, accurate, reliable, and highvalue information and knowledge. (c) Information technology must be able to increase the company's revenue generation level through an approach to prospective customers. Based on this, the information technology used by employees becomes a necessity for companies in helping their daily activities or activities.

An information system is an organized combination of people, software, communication network hardware, and data resources that collects, transforms, and disseminates information within an organization (Anggraeni, 2017) [3]. Anggraeni (2017) [3] also states that the function of the information system is (1) to improve the accessibility of existing data effectively and efficiently to users, without intermediary information systems (2) to improve the productivity of application development and system maintenance (3) to ensure the availability of quality and skills in the critical use of information systems (4) identify needs regarding information systems support skills (5) anticipate and understand the economic consequences (6) determine which investments will be directed to information systems (7) develop an effective planning process. The functions of this information system will be very helpful in the process of an organization's activities.

The presentation of the financial statements of non-profit organizations has its standards, so these standards are different from the standards used by business organizations in general. The accounting standards for financial reporting of non-profit organizations that are currently used are Interpretation of Financial Accounting Standards No. 35 (ISAK 35). Before the issuance of ISAK 35, non-profit accounting used Statement of Financial Accounting Standards No. 45 (PSAK 45) as a basic reference in making financial statements. PSAK 45 was issued by the Standard Board of the Indonesian Institute of Accountants (DSAK IAI) on December 23, 1997, and became effective on January 1, 2000. However, on April 8, 2011, PSAK 45 changed, the changes were in the title and scope.

PSAK 45, entitled financial reporting for non-profit organizations, does not classify government as a not-for-profit organization, while PSAK 45 (revised 2011) changes its title to financial reporting for non-profit entities, and the government is included in the scope of non-profit entities as regulated in PSAK 45 (revised 2011). For 20 years the accounting standards for non-profit organizations have not changed. On September 26, 2018 DSAK IAI has ratified three things, namely (1) Exposure Draft Amendment to Statement of Financial Accounting Standards No. 1 (DE Amendment to PSAK 1) regarding the presentation of financial statements regarding the title of the financial statements, (2) Exposure Draft of Financial Accounting 
Standards No. 35 (DE ISAK 35) regarding the presentation of financial statements of non-profit oriented entities and (3) Draft of Exposure Revocation Statement of Financial Accounting Standards No. 35. 13 (DE PPSAK 13) regarding the revocation of PSAK 45. DE ISAK 35 is effective starting January 1, 2020.

ISAK 35 is a new standard ratified by the Financial Accounting Standards Board of the Indonesian Institute of Accountants (DSAK IAI) regarding the presentation of financial statements of non-profit organizations. According to DE ISAK 35 (IAI, 2019) [9], financial statements of non-profit organizations consist of statements of financial position, statements of comprehensive income, statements of changes in net assets, statements of cash flows, and notes to financial statements. The function of the financial statements of non-profit organizations is to fulfill all the interests of users of financial statements, these interests include assessing the way management carries out the responsibility for managing the resources entrusted to them, as well as providing financial information that is useful in making economic decisions (IAI ISAK35, 2019) [9]. Therefore, guidelines are needed in the preparation of financial statements of non-profit organizations, so that the information presented can meet the needs of users and is easy to understand. The guideline that can be used in preparing the financial statements of non-profit organizations is ISAK 35.

The explanation above can be seen that the preparation of Financial Statements for non-profit organizations is very important. The Financial Report is not only a horizontal accountability report (society) but also a vertical accountability report (God Almighty). The fund management system in the mosque is still carried out thoroughly, resulting in the mosque's financial management is still traditional. The methods used in the financial recording and reporting process are mostly manual. Most of the mosques spread throughout Indonesia only record their reports based on cash in and cash out and then announced through the mosque notice board (Rini, 2019) [11]. Such reporting certainly indicates a missed understanding between users and managers of mosque funds, this can happen because information users (stakeholders) feel that the mosque's financia statements do not meet the criteria for correct presentation.

Increasing accountability in today's industrial revolution era will be very important to collaborate with computerized systems. Sophisticated technology that is appropriately responsive leads to faster development of information systems. Thus, non-profit organizations such as mosques that are closely related to people's daily lives need to make quality financial reports as a form of accountability not only to humans (hablumminannas) but also based on the most important responsibility, namely to Allah SWT (hablumminallah) as the owner of the universe. (Apriyanti, 2017) [4]. Shariah Enterprise Theory clearly explains that in every economic activity, including accountability not only horizontally but also vertically because the main stakeholder is Allah SWT. Shariah Enterprise Theory (SET) is a derivative concept of Enterprise Theory where SET has been internalized with Islamic values. The presence of SET can be used as legitimacy to include several understandings, including the concept of zakat, the concept of responsibility, the concept of ownership in Islam, and the concept of divine justice (Adil et al, 2019) [1]

Entering the all-digital era also requires all parties, especially stakeholders, which in this case the general public also needs to be welcome to the digital world starting from something simple but easy to understand and the information produced is more communicative. Based on what has been explained in the background, the problem that can be formulated is how to design web-based financial reports based on ISAK 35 at An-Nuur Mosque, Jember Regency?. ISAK 35 concerning the presentation of financial statements of non-profit-oriented entities clearly explains the provisions in the presentation of financial statements of non-profit organizations. The emergence of this standard hopes that non-profit organizations can implement it in the presentation of their financial statements. As an effort to improve the integrity of the management of funds in the mosque. Such a phenomenon concludes that the purpose of this study is to design or design web-based financial reports based on ISAK 35 at the An-Nuur Mosque, Jember Regency.

\section{Methodology}

In this study, the data that will be used are qualitative data types, where qualitative data is a type of data whose information is obtained from related informants which are usually in the form of interviews. Based on this, the type of data in this study is the sentence conveyed by the informant as the party who understands the most about the object of research. Nurjannah (2018) [10] said that research using qualitative data views the representation of informants as represented by the quality of the information provided by informants involved in this study.

Qualitative data is usually obtained from an objective interview process because it is interpreted by different people. The research was conducted to answer the existing problems, therefore each researcher will collect information from the field, and then the information will be processed by the researcher as qualitative data. Qualitative data is the source of a broad description and it contains an explanation of the processes that occur at the local scope. Qualitative data tends to lead researchers to be able to follow and understand each flow of events chronologically, assess cause and effect within the scope of the minds of local people, and obtain comprehensive and useful explanations. (Adnan, 2013) [2].

The source of data used in this study is primary data in the form of a survey conducted by researchers to obtain real-time data or data that develops every time at the An-Nuur Mosque as the research location. This primary data is identical to the active involvement or participation of the researcher to synchronize the required data with the data obtained by the researcher in the direct observation process at the research location.

The main data collection methods of this research are semistructured interviews and focus group discussions (Forum Group Discussions). Such data collection methods will go hand in hand with qualitative methods which are the type of this research. Researchers will conduct semi-structured interviews and focused group discussions to obtain qualitative data collected through credible sources of informants, namely the chairman of the mosque takmir, the mosque finance department (mosque treasurer), and other stakeholders in the An-Nuur Mosque environment as objects. research (community or mosque congregation)

Data analysis is carried out starting (start) data collection until the entire data collection process is carried out. The following are three stages of the data analysis process: (a) Data Reduction, this process is carried out by focusing attention and searching for research material from various reference sources that refer to the main problems that have been proposed in the problem formulation. (b) Data Presentation, Data presentation is done by interpretive method, which begins by explaining the problem formulation as an introduction proposed by the researcher. Then the data relating to the formulation of the problem is explained which is then connected to the theory that can answer the formulation of the problem. (c) Conclusion Drawing, Data collection, and analysis Qualitative research does not conclude the results in a hurry or haste, but gradually while consistently paying attention to any findings obtained since the initial step of data collection.

This study uses data validity testing with the two most appropriate tests, namely (a) Method Triangulation, this triangulation means that researchers can compare the information or data needed in different ways. For example, in this 
study, according to the data collection method mentioned earlier, to achieve the validity of the information or data related to this research, the researcher conducted semi-structured interviews with several mosque parties who knew about managing mosque financial statements, then to maintain consistency and the accuracy of the information obtained from the interview, the researchers used the triangulation method, namely by carrying out other methods such as focused discussions and field observations. (b) Triangulation of Data Sources. This type of triangulation is defined as the process of digging up the truth of certain information through various methods and sources of data acquisition. For example, the main data source from this study is an interview with the treasurer as the holder of the financial management authority at the mosque, then the researcher can also obtain supporting data sources such as documents or proof of transactions related to the mosque's cash income and expenditure which are included in the components of the financial statements which are the research variables. This is so that the data or information obtained from interviews can be more accurate. The example concludes that triangulation with data sources is a process of comparing and re-checking the accuracy of information obtained through different data forms and at different times. (c) The dependability test in this study was conducted by examining the entire research process. This test is carried out together with the supervisor regarding the technical and all research activities that have been carried out.
A web-based application that has been designed to compile financial reports, which is then carried out by researchers is to implement a web-based application in the preparation of AnNuur Mosque's financial statements. The preparation of this web-based computerized financial report will produce financial statements of the An-Nuur Mosque following ISAK 35. The following are the steps taken to make the financial statements of the An-Nuur Mosque based on the web-based ISAK 35:

1. Identify transactions owned by Masjid An-Nuur.

The transaction identification stage is the initial stage for researchers to examine in detail the transaction recording process carried out by the An-Nuur Mosque. Based on the data review, the recording of transactions carried out by the An-Nuur Mosque is still using the traditional method, namely manual recording. An-Nuur Mosque records cash income and disbursements using a simple cash book containing the transaction date column, the type of transaction that occurred, and the debit credit column which explains the recording as a reporting process which is carried out through a bulletin board which is carried out every third Friday of each month.

2. Classify the accounts owned by the An-Nuur mosque then input the account name data into the account menu that has been created. After the transaction identification stage, the researcher then made an account classification based on transaction data that often occurred at the An-Nuur Mosque.

\section{Result and Discussion}

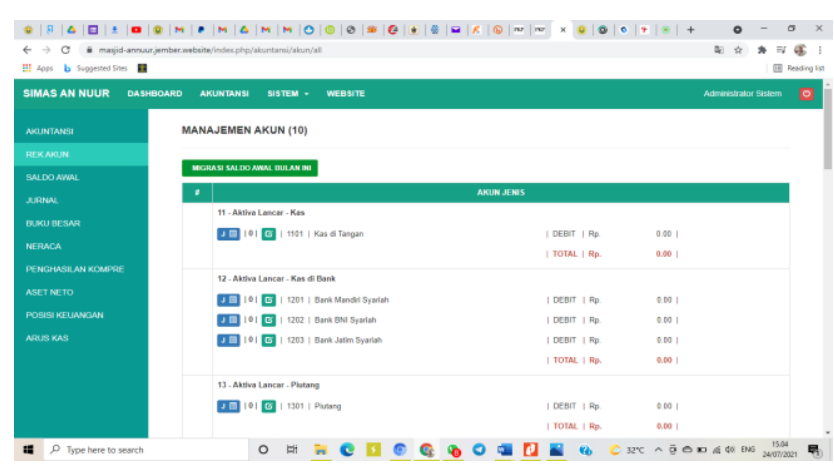

Fig 1: Account

3. Beginning Balance

Beginning balance is the sum of the numbers that the company had when it first did business on the balance sheet (Gray et al, 2006) [6]. The following is a web-based beginning balance display:

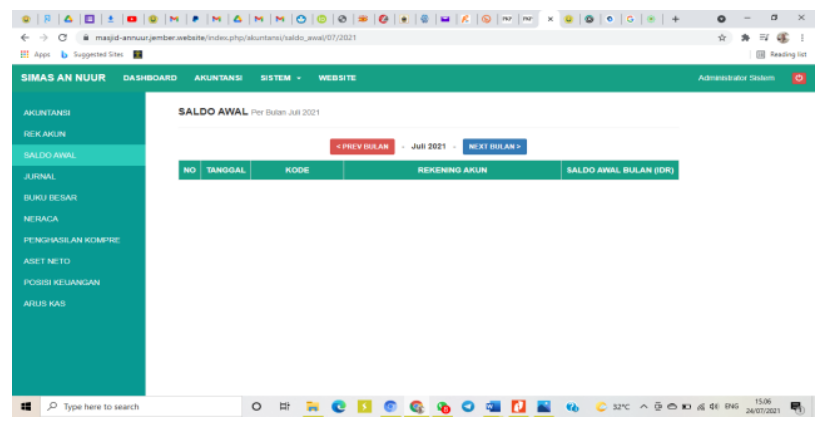

Fig 2: Beginning balance

4. Journal

Journal or recording is a form used to record all transaction activities that occur in order of date to tables that include information and the nominal amounts of debits and credits and have a final value that must be balanced. (Gray et al, 2006) [6]. The following is a journal in the web application: 


\section{GENERAL MANAGEMENT}

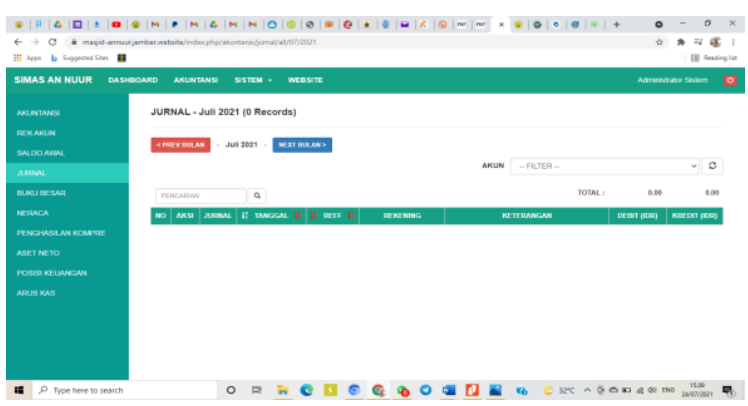

Fig 3: Journal

5. General Ledger

The definition of a general ledger is a book that contains an estimate of an overview of the effects of financial transactions due to changes in assets, liabilities, or capital in a company or organization. (IAI, 2019) [6]. Here is how the Ledger looks on the web

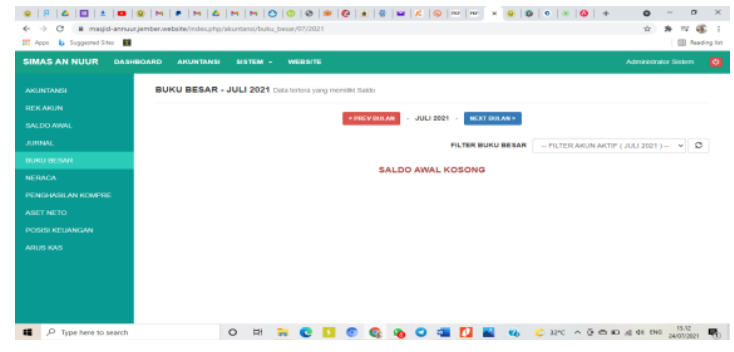

Fig 4: Ledger

6. Trial Balance

A trial balance is a bookkeeping or accounting report that lists the balances in each of the organization's general ledger accounts. (IAI, 2019) [6]. Here's what the Trial Balance looks like on the web:

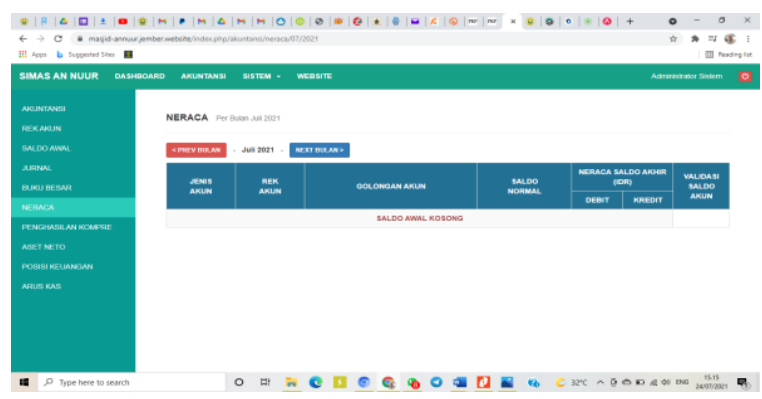

Fig 5: Trial Balance

7. Comprehensive Income Statement

The Comprehensive Income Statement describes the increase and decrease in the economic benefits of non-profit entities arising from receipts or revenues and expenses or expenses. (IAI ISAK 35, 2019) [9]. The following shows a web-based

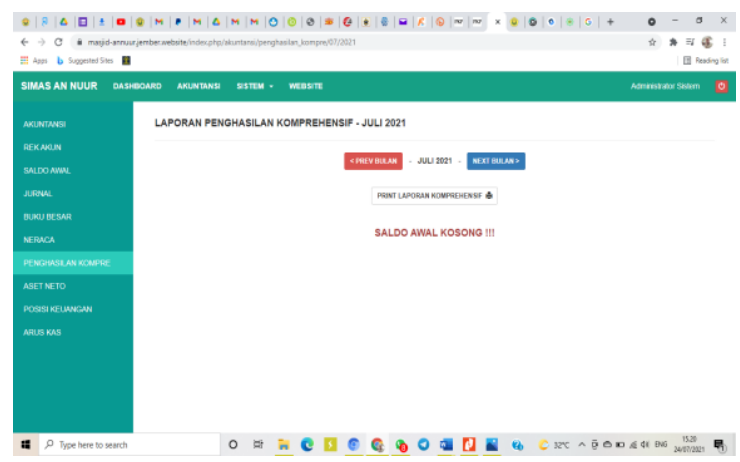

Fig 6: Comprehensive income 


\section{GENERAL MANAGEMENT}

8. Change Net Assets Statement

A non-profit organization based on ISAK 35 (IAI, 2019) [9]. required to make a statement of financial position in which it must also summarize the net asset items based on the limitations of the resource provider or without the limitation of the resource provider. Here's what the web-based Net Assets Report looks like:

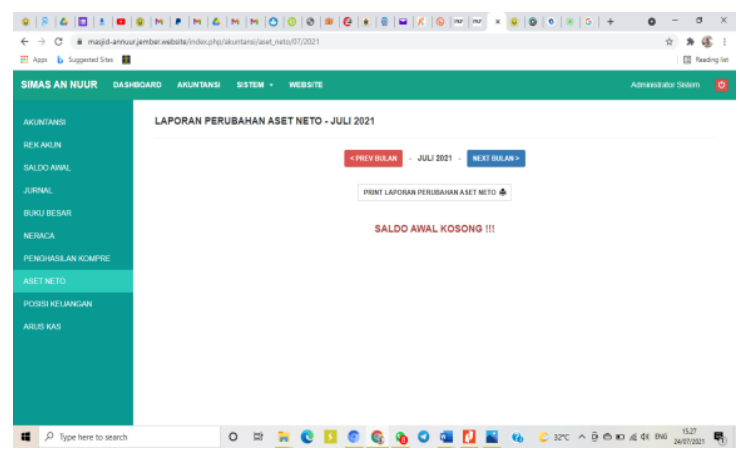

Fig 7: Statement of change in net asset

9. Statement of Financial Position

Statement of financial position that describes the position of assets, liabilities, and net assets at a certain time. (IAI, 2019) [8]. The following is a web-based view of the Statement of Financial Position:

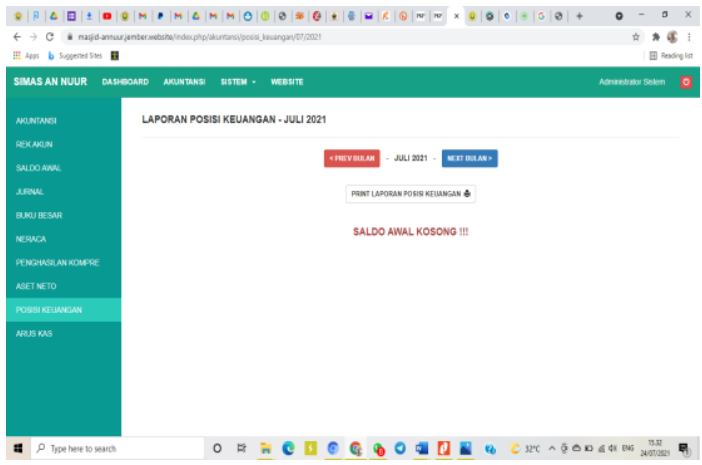

Fig 8: Statement of financial position

10. Cash Flow Statement

A cash flow statement is a report that shows the receipts and disbursements of cash and cash equivalents during a certain period which is grouped into operating activities, investing activities, and financing activities. (IAI, 2019) [7]. The following is a web-based Cash Flow Statement view:

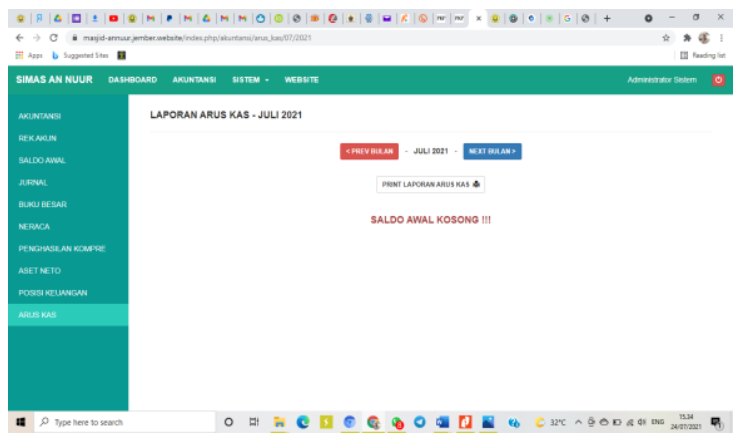

Fig 9: Statement of Cash Flow

\section{Conclusion}

The results of the researcher's analysis state that web-based financial statements require several stages, namely making a list of accounts menu, creating an initial balance menu, making a journal menu, creating a general ledger menu, making a trial balance menu, and making a financial report menu. After designing a web-based financial report, the researcher then compiles the An-Nuur Mosque's financial report by implementing the functions that have been designed from a web-based application. The process of implementing An-Nuur Mosque's financial statements on the web also consists of several stages, namely identifying transactions owned by An-Nuur Mosque, classifying the accounts owned by An-Nuur Mosque then inputting account name data into the account menu that has been created, input initial balance data into the initial balance menu designed using the web, carrying out the process of recording general journals on the journal menu that has been made, posting journalized data to the ledger, compiling a trial balance, compiling financial statements of An-Nuur mosque following ISAK 35. 


\section{GENERAL MANAGEMENT}

\section{Acknowledgment}

The authors would like to express gratitude to all references listed for supplying the part of the resources to complete this study. The author received no financial support for the research, authorship, and publication of this article.

\section{References}

[1] Mohamed Azam, M. A. (2013). Financial Management Practices of Mosques in Malaysia. Global Journal Al Thaqafah, 3(1), 23-29. doi:10.7187/gjat302013.03.01

[2] Adnan, M. A. (2013). The Financial Management Practices of the Mosques in the Special Region of Yogyakarta Province, Indonesia. Tazkia Islamic Finance and Business Review, 8 No.2, 120-142.

[3] Anggraeni, E.Y., 2017. Introduction to Information Systems. Andi Publisher.

[4] Apriyanti, H. W. (2017). Islamic Accounting: An Overview Between Theory And Practice. Indonesian Accounting Journal, 6(2), 131. doi: 10.30659/jai.6.2.131-140

[5] Arifin, Jabal Firdaus, and Suryo Pratolo. 2012. The Influence of the Quality of Regional Financial Information Systems on the
Satisfaction of Local Government Apparatuses Using the Delone and Mclean Model. Journal of Accounting \& Investment. Vol. 13 No. 1, pp. 28-34.

[6] Gray, R., Bebbington, J., \& Collison, D. (2006). NGOs, civil society and accountability: making the people accountable to capital. Accounting, Auditing \& Accountability Journal, 19(3), 319-348. doi:10.1108/09513570610670325

[7] Indonesian Institute of Accountants. (2019). Statement of Financial Accounting Standards No. 02 Statement of Cash Flows. Jakarta: Financial Accounting Standards Board, 02(02), p. 1-52.

[8] Indonesian Institute of Accountants. (2019). Statement of Financial Accounting Standards No. 1 Presentation of Financial Statements. Jakarta: Financial Accounting Standards Board, 1, p. 1-1.17.

[9] Indonesian Institute of Accountants. (2019). DE ISAK 35: Presentation of Financial Statements of Non-profit Oriented Entities. Indonesian Institute of Accountants. www.iaiglobal.or.id

[10] Nurjannah. (2018). Accountability of Mosque Financial Management: PSAK No. 45 Concerning Financial Reporting of Non-Profit Organizations. In Thesis (Issue 45).

[11] Rini, R. (2019). Financial Management of Mosques in Greater Jakarta. Journal of Islamic Accounting and Finance, 6(2), 109-126. doi: 10.35836/jakis.v6i2.1 